\title{
HIGH-STRENGTHENING OF CEMENT-TREATED CLAY BY MECHANICAL DEHYDRATION
}

\author{
Kiyonobu Kasama ${ }^{\text {i), Kouki Zen }}{ }^{\text {ii) }}$ and KIyoharu Iwataki ${ }^{\text {iii) }}$
}

\begin{abstract}
A technique called the cement-mixing and mechanical dehydration method (CMD) as one of recycling techniques for soft clay slurry is developed. In order to evaluate the effectiveness of the CMD for increasing the strength of soft clay, a series of unconfined compression tests and several durability tests were performed together with the literature review of unconfined compressive strength in cement-treated soils. Moreover, a series of constant strain rate consolidation tests were also performed to evaluate the effects of cement content and dehydration speed on the permeability of cementtreated clay. The following conclusions are obtained: 1) Literature review and theoretical considerations on the shear strength of cement-treated soils show that an additional treatment for the purpose of increasing the density of cementtreated specimen is effective for increasing the shear strength of cement-treated soil. 2) The mechanical dehydration of soft clay with high pressure is accelerated by cement mixing, where the coefficient of consolidation of cement-treated clay increases as the cement content increases. 3) The high-strength specimen having the unconfined compressive strength of more than $20 \mathrm{MPa}$ can be created from soft clay treated by the CMD with the cement content of over $20 \%$ and the dehydration pressure of $20 \mathrm{MPa}$.
\end{abstract}

Key words: cement, cement stabilization, dehydration, marin clay, recycle, unconfined compressive strength (IGC: D6/D10)

\section{INTRODUCTION}

Cement-treated soils (namely, cement mixed soils) have been developed in the field of geotechnical engineering, and cement-mixing has been widely utilized as a recycling technique for construction surplus soils, construction sludge, dredged materials and industrial wastes (e.g. Tang et al., 2001; Porbaha et al., 1999; Zou and Li, 1999). Tsuchida et al. (2001) reported basic engineering properties of cement-treated soils with lightweight additives, such as a foam or expanded polystyrol beads. The main factors affecting the shear strength of the cementtreated soils include the types and amounts of binder/ cement (e.g., Terashi and Tanaka, 1981; Clough et al., 1981), physico-chemical properties of the in situ soil (Kamon and Katsumi, 1999), curing conditions (Consoli et al., 2000) and effectiveness of the mixing process (Larsson, 2001, Omine et al., 1998).

Cement-treated soils can be utilized for future practical applications in various fields of geotechnical engineering provided that the strength can be well-controlled with a wide range of the strengths. For example, Elkins and Thompson (1997) reported recycling facilities changing dredged materials into non-hazard ceramic granules, while Tay et al. (2002) presented the potential use of marine clay mixed with industrial sludge as concrete aggregate material. Netzband et al. (2002) introduced a recycling facility at Hamburg port in Germany where dredged material has been used beneficially as a sealing material in the construction of the dredged material disposal sites and also utilized as raw material in brick fabrication. Soft clay, when reproduced as a stronger type of soil comparable to concrete material, can be used for such construction materials as blocks, bricks and tiles.

From this background, a technique called the cementmixing and mechanical dehydration method (CMD) as one of recycling techniques for soft clay slurry, construction surplus soil, etc. has been developed by the authors. In the CMD procedure, soft clay mixed with cement is dehydrated with high pressure for the purpose of increasing the strength. The purpose of this paper is to produce high-strength cement-treated clay having a comparable strength to concrete. First, a literature review is carried out to examine the maximum unconfined compressive strength of cement-treated soils and to clarify the sample preparation for increasing the strength. Then, in order to clarify the fundamental dehydration properties of cement-treated clay, a series of constant strain rate consolidation tests were performed as a function of

i) Research Associate, Graduate School of Engineering, Kyushu University, Japan (kasama@civil.kyushu-u.ac.jp).

ii) Professor, ditto.

iii) Ministry of Land Infrastructure and Transport, Kyushu Regional Development Bureau Director, Japan.

The manuscript for this paper was received for review on June 16, 2005; approved on November 17, 2006.

Written discussions on this paper should be submitted before November 1, 2007 to the Japanese Geotechnical Society, 4-38-2, Sengoku, Bunkyo-ku, Tokyo 112-0011, Japan. Upon request the closing date may be extended one month. 
dehydration speed and cement content. Finally, in order to evaluate the effect of mechanical dehydration with high pressure on the unconfined compressive strength of cement-treated clay, a series of unconfined compression tests and durability tests were performed on soft clay specimens prepared as a function of cement content, dehydration pressure and dehydration mode.

\section{LITERATURE REVIEW OF THE UNCONFINED COMPRESSIVE STRENGTH}

The strength of cement-treated soils is in the intermediate range of magnitude between that of soil and rock. Therefore, not only the approach from the viewpoint of soil mechanics but also the rock mechanics' approach is needed in the evaluation of the strength of cement-treated soil. Since the cement-treated soil is combined with a stabilizer such as cement, it is needless to say that the strength is deeply dependent on the mix proportion and curing condition similar to concrete. The strength properties of cement-treated soils have been widely examined through unconfined compression tests which are favored due to their simplicity and ability to represent properties at low confining pressures. It is known that the unconfined compressive strength, $q_{\mathrm{u}}$ of cement-treated clayey soils is equivalent to the undrained shear strength at zero consolidation pressure similar to cohesive soil, while $q_{\mathrm{u}}$ of cement-treated sandy soil is equivalent to the drained shear strength at zero consolidation pressure as reported by Zen et al. (1990). Accordingly, measured $q_{\mathrm{u}}$ for cement-treated soil is considered to be shear strength under a different drain condition depending on the soil type. However, in order to collect a number of data for the strength of cement-treated soils, the magnitude of $q_{\mathrm{u}}$ is used as a reference strength to express the shear strength of cement-treated soils in this paper. The maximum $q_{\mathrm{u}}$ in cement-treated soils was investigated based on the literature review of the proceedings of $26^{\text {th }}$ to $34^{\text {th }}$ Japan National Conference on Geotechnical Engineering. Further, the relationships between the maximum $q_{\mathrm{u}}$ and the physical properties of an original soil before cement-mixing, cement content and sample preparation were also examined.

From the content of the proceedings, soil type, initial water content, wet soil density, plasticity index, weight ratio of cement to dried soil (called "cement content"), cement weight per wet soil volume of $1 \mathrm{~m}^{3}$ (called "cement amount"') and curing period were examined together with the magnitude of $q_{\mathrm{u}}$. Soil type was classified into gravel, sandy soil, cohesive soil, organic soil, volcanic cohesive soil, waste and unusual soil according to JGS-0051 (Japanese Geotechnical Society, 2000). Cohesive soil was classified into clay and silt if indicating liquid limit and plasticity index. Volcanic soil was classified into Kanto loam and Kuroboku (volcanic pumiceous black soil). As for unusual soil, Masado (decomposed granite), peat and diatom soil were selected.

Table 1 summarizes sample number, mean $q_{\mathrm{u}}$, maximum $q_{\mathrm{u}}$ and the coefficient of variability of $q_{\mathrm{u}}, \mathrm{COV}_{q_{\mathrm{u}}}$. It
Table 1. Statistical value for unconfined compressive strength of cement-treated soil

\begin{tabular}{c|l|c|c|c|c}
\hline \multicolumn{2}{c|}{ Soil type } & Number & $\begin{array}{c}\text { Mean } \\
(\mathrm{MPa})\end{array}$ & COV $_{q_{\mathrm{u}}}$ & $\begin{array}{c}\text { Maximum } \\
(\mathrm{MPa})\end{array}$ \\
\hline \multicolumn{2}{c|}{ Gravel } & 3 & 1.58 & 0.08 & 1.70 \\
\hline \multirow{2}{*}{ Sandy soil } & 97 & 4.77 & 0.89 & 20.00 \\
\cline { 2 - 6 } Cohesive soil & Silt & 57 & 1.92 & 1.41 & 11.50 \\
\cline { 2 - 6 } & Clay & 24 & 4.72 & 1.57 & 25.00 \\
\hline \multirow{2}{*}{ Organic soil } & 45 & 2.92 & 0.82 & 8.00 \\
\hline \multirow{3}{*}{ Volcanic soil } & Kanto loam & 57 & 1.86 & 0.96 & 6.00 \\
\cline { 2 - 6 } & Kuroboku & 11 & 0.26 & 0.85 & 0.87 \\
\cline { 2 - 6 } & Other & 22 & 0.63 & 1.50 & 4.00 \\
\hline \multirow{2}{*}{ Waste } & 18 & 3.49 & 1.20 & 18.00 \\
\hline & Masado & 12 & 10.74 & 0.64 & 23.00 \\
\cline { 2 - 6 } & Peat & 10 & 0.43 & 1.10 & 1.75 \\
\cline { 2 - 6 } & Diatom soil & 4 & 3.24 & 0.61 & 5.50 \\
\hline
\end{tabular}

$\mathrm{COV}_{q_{\mathrm{u}}}$ : the coefficient of variability of unconfined compressive strength

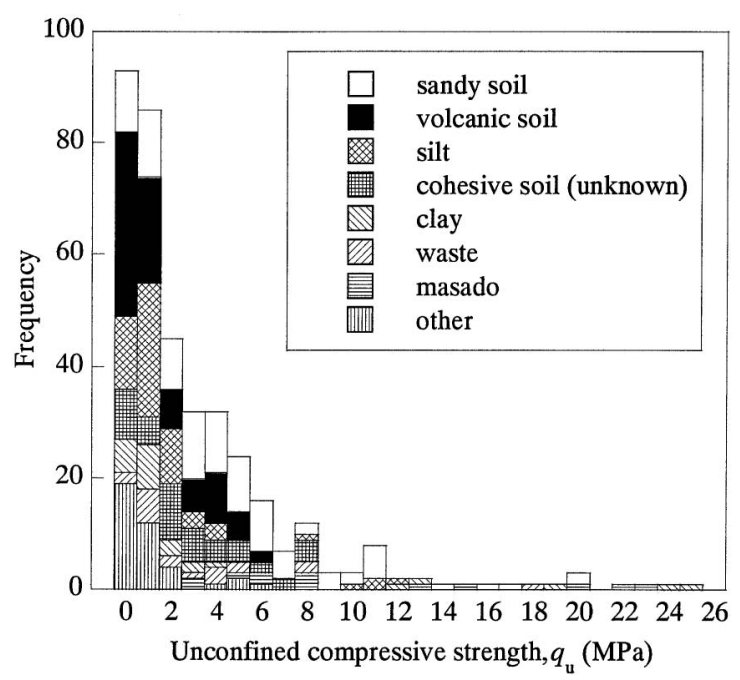

Fig. 1. Histogram of unconfined compressive strength

is observed that three of the largest mean $q_{\mathrm{u}}$ values are obtained in Masado, sandy soil and cohesive soil in order of value. $\mathrm{COV}_{q_{\mathrm{u}}}$ except for gravel ranges form 0.6 to 1.6 , which is much larger than that expected for the undrained shear strength of natural clays. Clay, volcanic soil and silt indicate high $\mathrm{COV}_{q_{\mathrm{u}}}$ suggesting that the $\mathrm{COV}_{q_{\mathrm{u}}}$ increases with decreasing grain size of original soil. As for the maximum $q_{\mathrm{u}}, 25 \mathrm{MPa}, 23 \mathrm{MPa}$ and $20 \mathrm{MPa}$ are obtained in clay, Masado and sandy soil, respectively.

Figure 1 shows the histogram of $q_{\mathrm{u}}$ for all the samples. The results of gravel, organic soil, peat and diatom soil are shown in the category of "other" in Fig. 1. It shows that the frequency drastically decreases with increasing strength and about $90 \%$ of all data ranges less than 8 $\mathrm{MPa}$. Comparing the strength in terms of soil type, sandy soil and Masado indicate larger strength suggesting that 


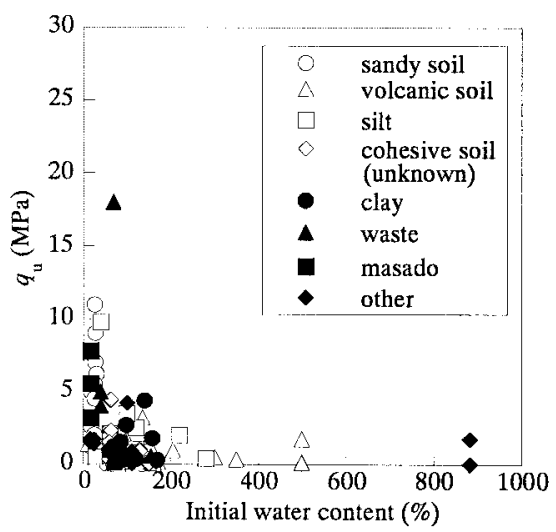

(a) Initial water content

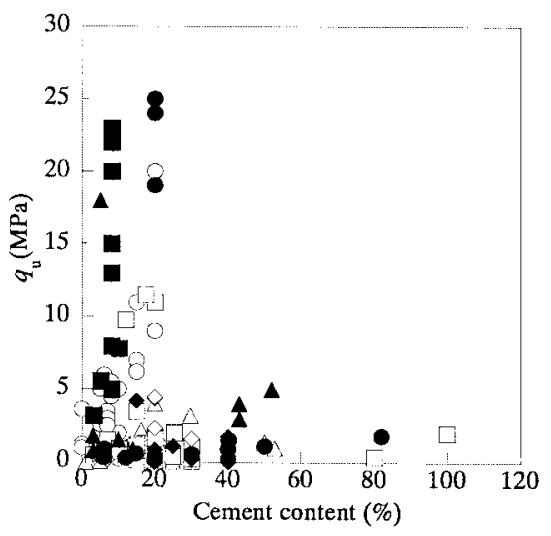

(d) Cement content

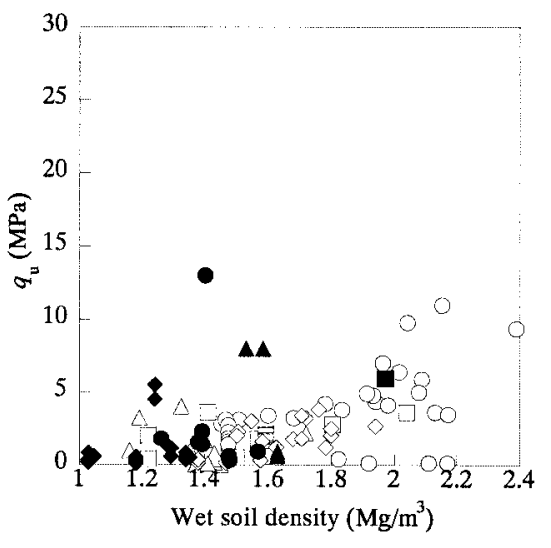

(b) Wet soil density

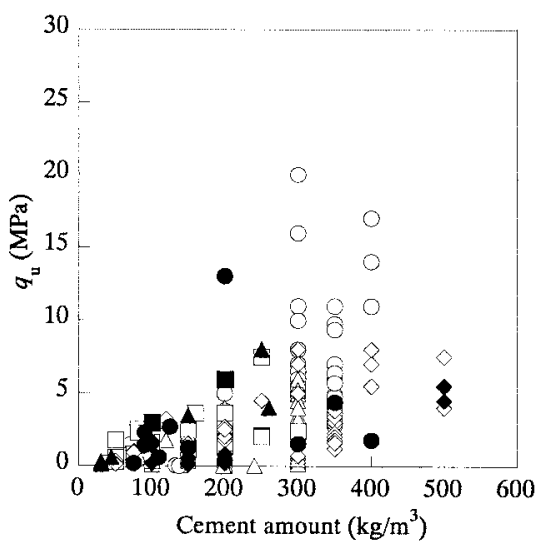

(e) Cement amount

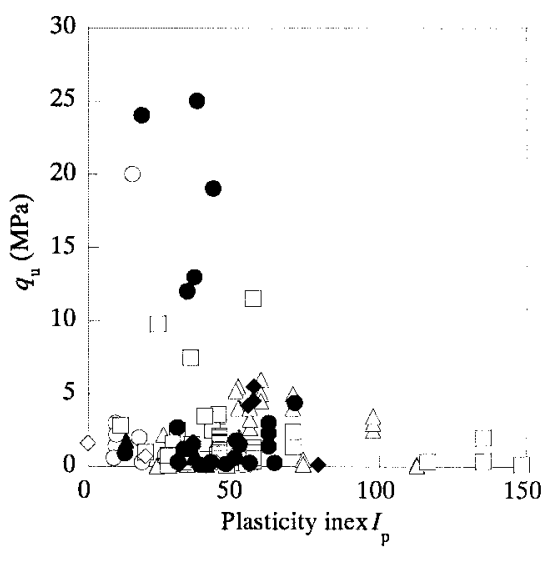

(c) Plasticity index $I_{\mathrm{p}}$

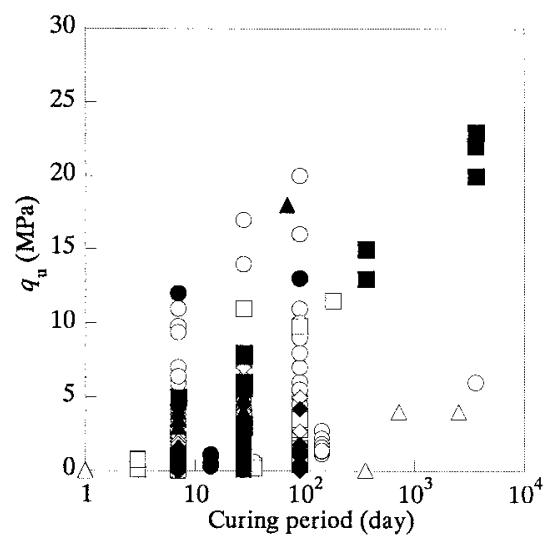

(f) Curing period

Fig. 2. $q_{\mathrm{u}}$ against parameter related to cement-treated soil

$q_{\mathrm{u}}$ of cement-treated soils generally increases with increasing grain size. Based on the results of literature review, $q_{\mathrm{u}}$ more than $20 \mathrm{MPa}$ is defined as a highstrength, which is an objective strength obtained by the CMD in this paper.

Figure 2 shows the relationships between $q_{\mathrm{u}}$ and six indexes (initial water content, wet soil density, plasticity index, cement content, cement amount and curing period). It should be noted that there are some lacking indexes in data sets of $q_{\mathrm{u}}$, even though cement content and cement amount are converted mutually as far as possible. The following findings were obtained from Fig. 2:

(1) $q_{\mathrm{u}}$ decreases with increasing initial water content, while most of the initial water contents are fewer than $200 \%$ (Fig. 2(a)). In addition, $q_{\mathrm{u}}$ increases with increasing wet soil density and the increase in the rate of $q_{\mathrm{u}}$ against wet soil density depends on the soil type (Fig. 2(b)). It can be concluded that $q_{\mathrm{u}}$ of cement-treated soils depends on the specimen density (water content), and also increases with increasing density irrespective of the soil type.

(2) $q_{\mathrm{u}}$ is not dependent on the plasticity index (Fig. 2(c)). $q_{\mathrm{u}}$ greater than $20 \mathrm{MPa}$ is obtained in cohesive soil with the plasticity index of 10-50 and in sandy soil with the plasticity index of about 10 .
(3) There is no strong correlation between $q_{\mathrm{u}}$ and cement content based on the results that highstrength is not obtained for specimens with the cement content of over $30 \%$ (Fig. 2(d)). In addition, as the cement amount showing a high-strength in Fig. 2(d) is roughly plotted to be around $100 \mathrm{~kg} / \mathrm{m}^{3}$ in Fig. 2(e), it can be seen that there is also no strong correlation between $q_{\mathrm{u}}$ and cement amount. From Figs. 2(d) and 2(e), $q_{u}$ greater than $15 \mathrm{MPa}$ was obtained in Masado with cement content of $8 \%$, in clay with cement content of $20 \%$ and in sandy soil with cement amount of $300 \sim 400 \mathrm{~kg} / \mathrm{m}^{3}$. The current research suggests that it is possible to produce a high strength specimen irrespective of the soil type, cement content and cement amount.

(4) $q_{\mathrm{u}}$ increases with curing period (Fig. 2(f)). Especially, $q_{\mathrm{u}}$ for cement-treated Masado is still increasing beyond the curing period of 10 years.

In order to investigate the details for producing a highstrength cement-treated soil, Table 2 summarizes soil physical properties, cement compositions (cement content and cement amount), and sample preparations for cement-treated soils indicating the largest $q_{\mathrm{u}}$ values.

The cement-treated soil with the largest $q_{\mathrm{u}}$ value was Kawasaki clay (initial water content $=102.3 \%, \rho_{\mathrm{s}}=2.633$ $\mathrm{Mg} / \mathrm{m}^{3}, w_{\mathrm{L}}=71.8 \%, I_{\mathrm{p}}=37.4$, sand content $=4 \%$, silt 
Table 2. Physical property of soil and sample preparation for maximum $q_{\mathrm{u}}$

\begin{tabular}{|c|c|c|c|}
\hline & Kawasaki clay & Masado & Toyoura sand* \\
\hline$q_{\mathrm{u}}$ & $25 \mathrm{MPa}$ & $23 \mathrm{MPa}$ & $20 \mathrm{MPa}$ \\
\hline Soil type & Clay & Unusual soil & Sandy soil \\
\hline Cement type & Portland & Portland & $\begin{array}{l}\text { Portland } \\
\text { blast-furnace slag } \\
\text { cement type B }\end{array}$ \\
\hline Cement content & $20 \%$ & $8 \%$ & $300 \mathrm{~kg} / \mathrm{m}^{3}$ \\
\hline Water content & $102.3 \%$ & $12.0 \%$ & $39.5 \%$ \\
\hline$\rho_{\mathrm{s}}$ & $2.633 \mathrm{Mg} / \mathrm{m}^{3}$ & $2.620 \mathrm{Mg} / \mathrm{m}^{3}$ & $2.700 \mathrm{Mg} / \mathrm{m}^{3}$ \\
\hline$w_{\mathrm{L}}$ & $71.8 \%$ & $35.7 \%$ & - \\
\hline$I_{\mathrm{p}}$ & 37.4 & 7.6 & - \\
\hline Gravel content & $0 \%$ & $48 \%$ & $0 \%$ \\
\hline Sand content & $4 \%$ & $38 \%$ & $100 \%$ \\
\hline Fine content & $96 \%$ & $14 \%$ & $0 \%$ \\
\hline Silt content & $45 \%$ & - & $0 \%$ \\
\hline Clay content & $51 \%$ & - & $0 \%$ \\
\hline$L_{\mathrm{i}}$ & $10.9 \%$ & - & - \\
\hline Curing condition & Under water & Standard curing condition ${ }^{* *}$ & Standard curing condition $* *$ \\
\hline Curing period & 28 days & 10 years & 91 days \\
\hline Additional treatment & $\begin{array}{l}\text { Consolidation by } \\
10 \mathrm{MPa}\end{array}$ & $\begin{array}{l}\text { Compaction with } \\
\text { rammer of } 2.5 \mathrm{~kg}\end{array}$ & $\begin{array}{l}\text { Consolidation by } \\
0.1 \mathrm{MPa} \text { for } 24 \text { hours }\end{array}$ \\
\hline Reference & Morita et al. (1992) & Mishima et al. (1993) & Nakama et al. (1998) \\
\hline
\end{tabular}

*: Toyoura sand mixed with diatom soil by $20 \%$ in dry weight

$* *$ : Temperature $=21 \pm 3^{\circ}$, Humidity $\geq 95 \%$

content $=45 \%$, clay content $=51 \%, L_{\mathrm{i}}=10.9 \%$ ) $\operatorname{mixed}$ with cement $20 \%$. The characteristic of sample preparation was to dehydrate the specimen with a pressure of 10 $\mathrm{MPa}$ after cement-mixing, and then curing the specimen in underwater condition. The specimen cured for 28 days had $q_{\mathrm{u}}$ of $25 \mathrm{MPa}$.

The cement-treated soil with the second largest $q_{\mathrm{u}}$ value was Masado (initial water content $=12 \%, \rho_{\mathrm{s}}=2.620 \mathrm{Mg}$ / $\mathrm{m}^{3}, \quad w_{\mathrm{L}}=35.7 \%, \quad I_{\mathrm{p}}=7.6$, gravel content $=4 \%$, sand content $=37.5 \%, F_{\mathrm{c}}=14.2 \%$, clay content $=51 \%, L_{\mathrm{i}}=$ $10.9 \%$ ) mixed with cement $8 \%$. The characteristics of sample preparation was to adjust the water content after cement-mixing to an optimum water content of original soil by compacting with rammer of $2.5 \mathrm{~kg}, 25$ times each layer according to JGS-0811 (JGS, 2000). After the sample compaction, specimens were cured under the temperature of $21 \pm 3^{\circ}$ and the humidity of more than 95\% (called “'standard curing condition") for 6 days. Then, specimens were cured in underwater condition at the temperature of $21 \pm 3^{\circ}$ for a day. Finally, specimens were cured under the standard curing condition for 10 years. The $q_{\mathrm{u}}$ cured for 7 days, 28 days, 1 year and 10 years were $5 \mathrm{MPa}, 8 \mathrm{MPa}, 13 \mathrm{MPa}$ and $23 \mathrm{MPa}$, respectively.

The soil with the third largest $q_{\mathrm{u}}$ value was Toyoura sand $\left(\rho_{\mathrm{s}}=2.700 \mathrm{Mg} / \mathrm{m}^{3}\right.$, sand content $\left.=100.0 \%\right)$ mixed with diatom soil $20 \%$ to enhance pozzolan reaction of cement. The initial water content of the mixture was
$39.5 \%$, and the cement content of Portland blast-furnace slag cement type $B$ is $300 \mathrm{~kg} / \mathrm{m}^{3}$. After cement-mixing in mold $(\phi 300 \mathrm{~mm} \times$ height $360 \mathrm{~mm})$, the mixture was consolidated with the vertical stress of $0.1 \mathrm{MPa}$ for 24 hours. After the consolidation, specimens were cured under the standard curing condition. The specimen cured for 91 days had $q_{\mathrm{u}}$ of $20 \mathrm{MPa}$.

It can be concluded that excessive cement content and cement amount are not necessary for high-strengthening cement-treated specimens. On the other hand, the common characteristics of these sample preparations were to perform additional treatments for the purpose of increasing the specimen density by consolidation and compaction after cement-mixing.

\section{THEORETICAL CONSIDERATION ON THE HIGH- STRENGTHENING}

In the earlier study (Kasama et al., 2006), the undrained shear strength of cement-treated soils was evaluated based on the results of isotropic consolidation and undrained triaxial shear compression tests. The undrained shear strength of cement-treated soil can be evaluated by dividing the stress state into normally consolidated and quasi-over consolidated regions irrespective of the different soil types. The undrained shear strength slightly increases with the increasing confining pressure under the quasi-over consolidation and then increases at 


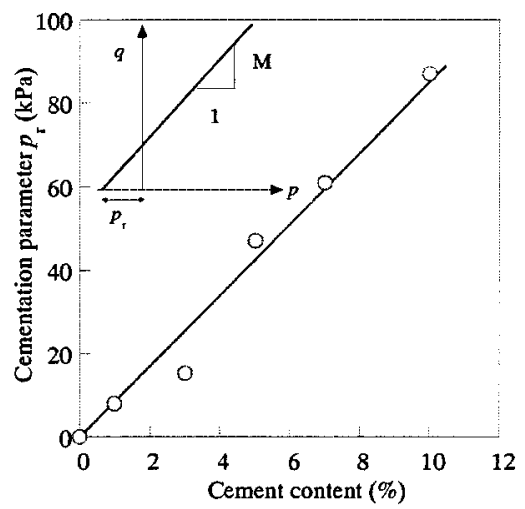

(a) Cementation parameter $p_{\mathrm{r}}$ and cement content

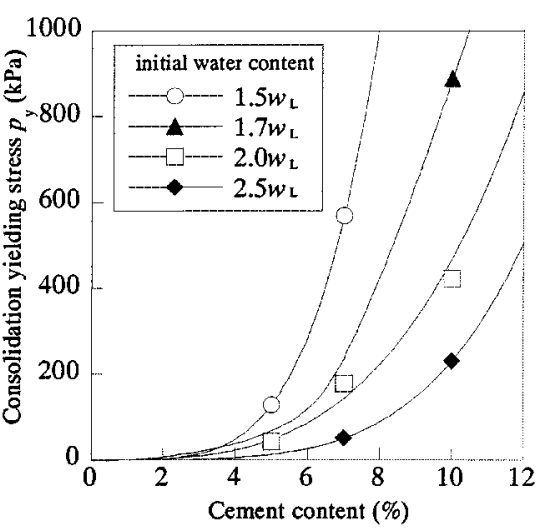

(b) $p_{y}^{\prime}$ and cement content

Fig. 3. The values of $p_{\mathrm{r}}$ and $p_{y}^{\prime}$

a constant rate in the normally consolidated state. The equivalent undrained shear strength ratio $s_{\mathrm{u}} /\left(p_{\mathrm{c}}^{\prime}+p_{\mathrm{r}}^{\prime}\right)$ can be expressed as;

$$
\begin{aligned}
& \frac{S_{\mathrm{u}}}{\left(p_{\mathrm{c}}^{\prime}+p_{\mathrm{r}}^{\prime}\right)}=\alpha \times R^{n} \\
& R=\frac{p_{\mathrm{y}}^{\prime}+p_{\mathrm{r}}^{\prime}}{p_{\mathrm{c}}^{\prime}+p_{\mathrm{r}}^{\prime}}
\end{aligned}
$$

where, $\alpha$ and $n$ are experimental parameters, and $p_{\mathrm{c}}^{\prime}$ is a consolidation pressure under undrained shearing. $p_{\mathrm{r}}^{\prime}$ is a cementation parameter representing the cementation effect. Yield stress ratio $R$ is defined by Eq. (1b) to express a stress state in quasi-over consolidation. This yield stress ratio is equivalent to the overconsolidation ratio for cases where $p_{\mathrm{r}}^{\prime}=0$. Characteristics of Eq. (1) are:

(1) The equivalent undrained shear strength ratio of cement-treated soils, $s_{\mathrm{u}} /\left(p_{\mathrm{c}}^{\prime}+p_{\mathrm{r}}^{\prime}\right)$, can be evaluated as a unique function of the yield stress ratio, $R$ irrespective of cement content and initial soil density.

(2) In case of $p_{\mathrm{r}}^{\prime}=0$, Eq. (1a) is equivalent to the undrained shear strength evaluation for overconsolidated cohesive soil (Murthy et al., 1982; Mitachi and Kitago, 1976; Mayne, 1980).

(3) Cementation parameter $p_{\mathrm{r}}^{\prime}$ and yield stress ratio $R$ are primal factors influencing the undrained shear strength of cement-treated soils.

The values of $p_{\mathrm{r}}^{\prime}$ and $p_{\mathrm{y}}^{\prime}$ in Eq. (1) are dependent on cement content as shown in Fig. 3. Figure 3(a) is the relationship between $p_{\mathrm{r}}^{\prime}$ and cement content showing that $p_{\mathrm{r}}^{\prime}$ increases linearly as cement content increases. Figure 3 (b) is the relationship between consolidation yield stress $p_{\mathrm{y}}^{\prime}$ and cement content showing that $p_{\mathrm{y}}^{\prime}$ increases exponentially with the cement content, but decreases with increasing initial water content.

Here, Eq. (1) is analyzed for the purpose of obtaining a high-strength cement-treated soil assuming that $\alpha$ and $n$ are constant irrespective of cement content. In order to increase $s_{\mathrm{u}}$ in Eq. (1a), it is effective to increase $\left(p_{\mathrm{c}}^{\prime}+p_{\mathrm{r}}^{\prime}\right)$ and $R$. However, it can be considered that the contribution of $\left(p_{\mathrm{c}}^{\prime}+p_{\mathrm{r}}^{\prime}\right)$ to the increment of strength is relatively small at low range of consolidation pressure such as an unconfined condition. On the other hand, $R$ can be expected to increase by increasing the value of $p_{\mathrm{y}}^{\prime}$, which is one of components of $R$ in Eq. (1b). In order to increase $p_{y}^{\prime}$, it is effective to increase cement content and increase the formation density of specimen (decrease the initial water content) as shown in Fig. 3(b). Finally, a mechanical dehydration with high pressure following cement-mixing can be proposed to obtain a high-strength cement-treated soil in this paper.

\section{HIGH PRESSURE DEHYDRATION PROPERTY}

\section{Sample Preparation and Test Procedure}

In order to clarify the fundamental dehydration properties of cement-treated clay under high pressure, a series of constant strain rate consolidation tests according to the JGS-0412 (JGS, 2000) were performed. Soft clays dredged at Kumamoto and Ube ports in Japan were used to prepare cement-treated specimens (called "Kumamoto clay" and "Ube clay", respectively). The physical properties of Kumamoto and Ube clays are $\rho_{\mathrm{s}}=2.614$ $\mathrm{Mg} / \mathrm{m}^{3}, w_{\mathrm{L}}=101 \%, I_{\mathrm{p}}=63.8$ and $\rho_{\mathrm{s}}=2.571 \mathrm{Mg} / \mathrm{m}^{3}, w_{\mathrm{L}}=$ $132 \%, I_{\mathrm{p}}=90.9$, respectively. Kumamoto and Ube clays in slurry of $1.5 w_{\mathrm{L}}$ were mixed with cement content $10 \%$ and $20 \%$ of Portland blast-furnace slag cement type B. After careful mixing for 10 minutes, the mixture was gently poured into the mold $(60 \mathrm{~mm}$ in diameter and 20 $\mathrm{mm}$ in height) by spoon. In order to remove air bubbles in the mixture, the mold with the mixture was thoroughly tapped in the lower part of the mold with a hammer, and immediately followed by constant strain rate consolidation tests to a consolidation pressure of $5 \mathrm{MPa}$. In order to raise the degree of saturation of specimen, a back pressure of $198 \mathrm{kPa}$ was applied in the consolidation process. The constant strain rate consolidation test was started in 5 minutes after finishing cement-mixing. In order to examine the effect of dehydration speed on the dehydration properties of cement-treated clay, the constant strain rates $r$ of $0.014,0.050,0.140$ and $0.200 \mathrm{~mm} /$ min were selected. The test conditions are summarized in Table 3 . 


\section{Consolidation Pressure and Cement Content}

Figure 4 shows the relationship between consolidation pressure and the elapsed time from starting consolidation for cement-treated Kumamoto clay. The constant strain rate, $r$, for Figs. 4(a) and 4 (b) are $0.014 \mathrm{~mm} / \mathrm{min}$ (the smallest case) and $0.200 \mathrm{~mm} / \mathrm{min}$ (the largest case), respectively. It can be observed that the consolidation pressure slightly increases at the low range of consolidation pressure and then increases sharply at the end of consolidation up to $5 \mathrm{MPa}$. The consolidation pressure of $r=0.014 \mathrm{~mm} / \mathrm{min}$ for a given elapsed time over 200 minutes increases with increasing cement content, while the relationships between consolidation pressures and elapsed time for $r=0.200 \mathrm{~mm} / \mathrm{min}$ show similar trend irrespective of the cement content. Accordingly, it can be seen that the effect of the elapsed time on the dehydration properties increases with the increasing elapsed time as the chemical reaction of cement agent is a function of the elapsed time. In other words, the elapsed time has little influence on the dehydration properties temporarily after cement-mixing, which is roughly estimated to be 70 minutes from Fig. 4(b). Similarly, Watabe et al. (2001) had reported that there was no strength increase in

Table 3. Experimental condition for one-dimensional consolidation tests using constant rate of strain loading

\begin{tabular}{l|l}
\hline \multicolumn{1}{c|}{ Soil } & \multicolumn{1}{c}{$\begin{array}{c}\text { Kumamoto clay } \\
\text { Ube clay }\end{array}$} \\
\hline Cement type & $\begin{array}{l}\text { Portland blast-furnace } \\
\text { slag cement type B }\end{array}$ \\
\hline Cement content & $0,10,20 \%$ \\
\hline Size of specimen & $\phi 60 \mathrm{~mm} \times \mathrm{H} 20 \mathrm{~mm}$ \\
\hline Initial water content & $1.5 w_{\mathrm{L}}$ \\
\hline Maximum loading stress & $5 \mathrm{MPa}$ \\
\hline Constant strain rate & $0.014,0.050$, \\
& $0.140,0.200(\mathrm{~mm} / \mathrm{min})$ \\
\hline
\end{tabular}

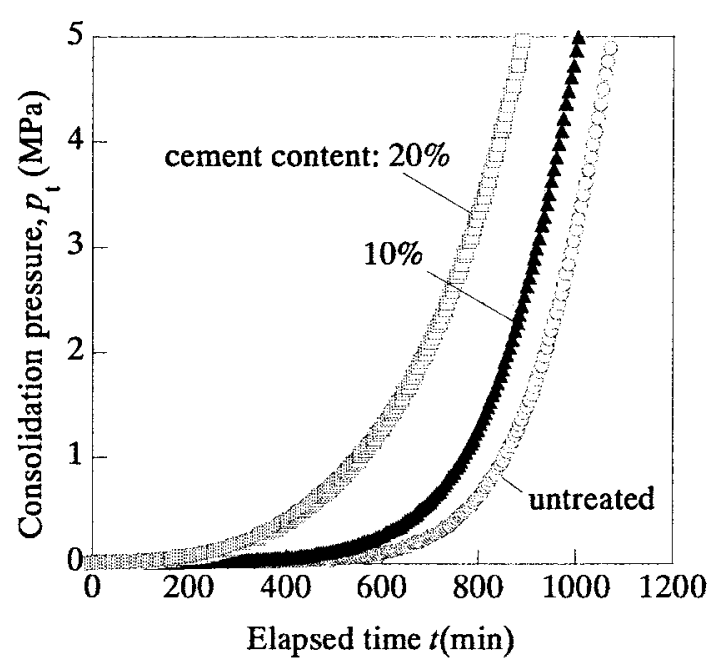

(a) Kumamoto clay, $r=0.014 \mathrm{~mm} / \mathrm{min}$ cement-treated clay for about 30 minutes after cementmixing based on the results of vane shear test for cementtreated clay.

\section{e- $\log p_{\mathrm{t}}$ Relationship}

Figure 5 shows the $e-\log p_{\mathrm{t}}$ for cement-treated Kumamoto clay with $r=0.014 \mathrm{~mm} / \mathrm{min}$. The void ratio of untreated clay remarkably decreases up to about 0.1 $\mathrm{MPa}$, which was supposed to be due to the stress relaxation between specimen and test apparatus, and then decreases linearly in $e-\log p_{\mathrm{t}}$ space. On the other hand, the void ratio for a given consolidation pressure increases with increasing cement content, while the difference of void ratio between cement-treated and untreated clays decreases as the consolidation pressure increases. Similar results were also obtained in cement-treated Ube clay as shown in Kasama et al. (2002). Kusakabe and Morio (1995), Miura et al. (2001) and Rotta et al. (2003) had also reported similar characteristics for cement-treated Kaolin (cement amount $8 \mathrm{~kg} / \mathrm{m}^{3}$ and one-dimensional consolidation pressure of $4.9 \mathrm{kPa}$ ), cement-treated Ariake clay (the ratio of clay and water/cement ratio of 7.5, 10 and 15, and the initial water content of $1.0,1.5,2.0$ and $3.0 w_{\mathrm{L}}$ ) and cement-treated silty sand (cement content of $0-3 \%$ and curing isotropic stress of $98-1960 \mathrm{kPa}$ ), respectively.

Figure 6 is the $e-\log p_{\mathrm{t}}$ for cement-treated Kumamoto clay with cement content of $20 \%$ as a function of the constant strain rate. It can be seen that the $e-\log p_{\mathrm{t}}$ with $r$ $=0.140 \mathrm{~mm} / \mathrm{min}$ coincides with that of $r=0.200 \mathrm{~mm} /$ min suggesting that there is no influence of the chemical reaction of cement agent on the $e-\log p_{\mathrm{t}}$ relationships for the both constant strain rate. It can be characterized that, however, $e-\log p_{\mathrm{t}}$ relationship shifts to positive side of $p_{\mathrm{t}}$ with decreasing $r$, and especially $e-\log p_{\mathrm{t}}$ with $r=0.014 \mathrm{~mm} / \mathrm{min}$ does not even show linear relationships in $e-\log p_{\mathrm{t}}$ space, which is supposed to be due to continuous generations and degradations of cementation produced by the chemical reaction of cement agent in

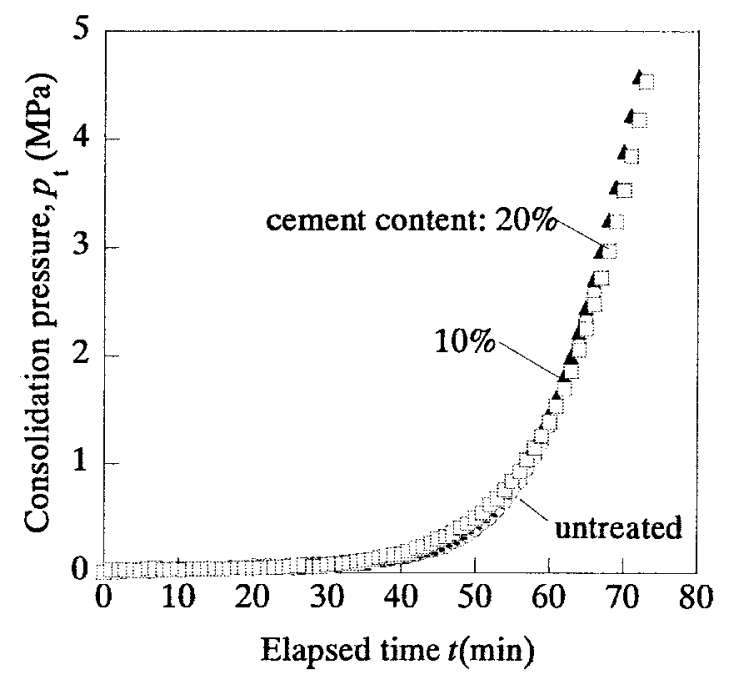

(b) Kumamoto clay, $r=0.200 \mathrm{~mm} / \mathrm{min}$

Fig. 4. Consolidation pressure against elapsed time 


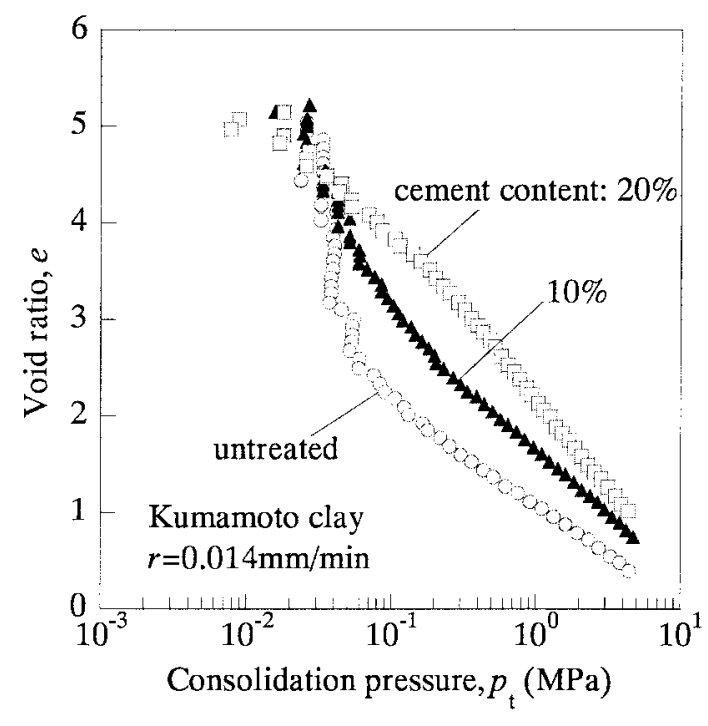

Fig. 5. $e-\log p_{\mathrm{t}}$ in terms of cement content

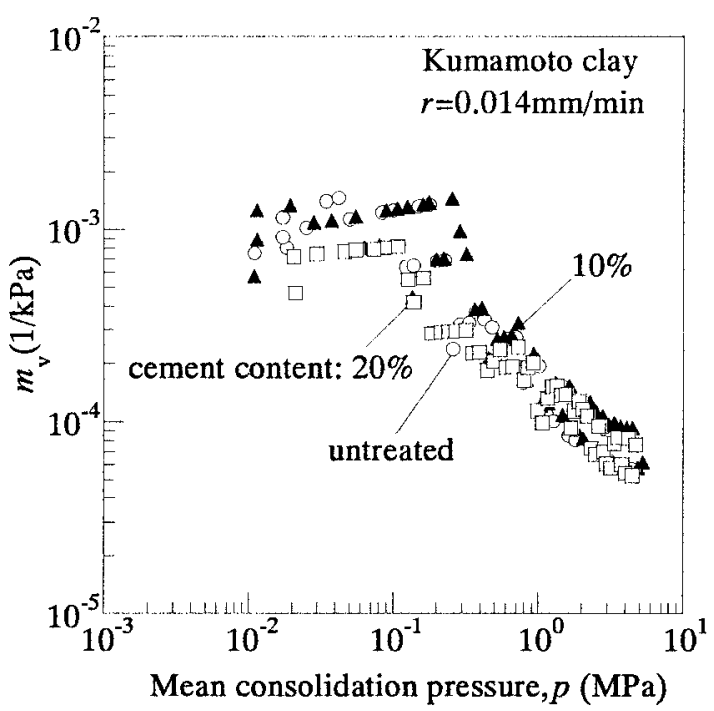

(a) Cement content

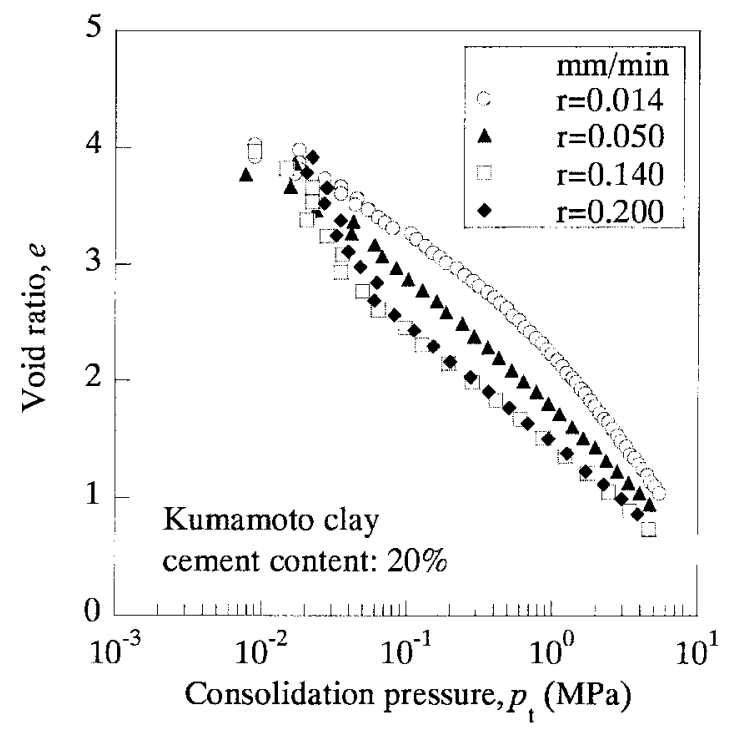

Fig. 6. $e-\log p_{\mathrm{t}}$ in terms of constant strain rate

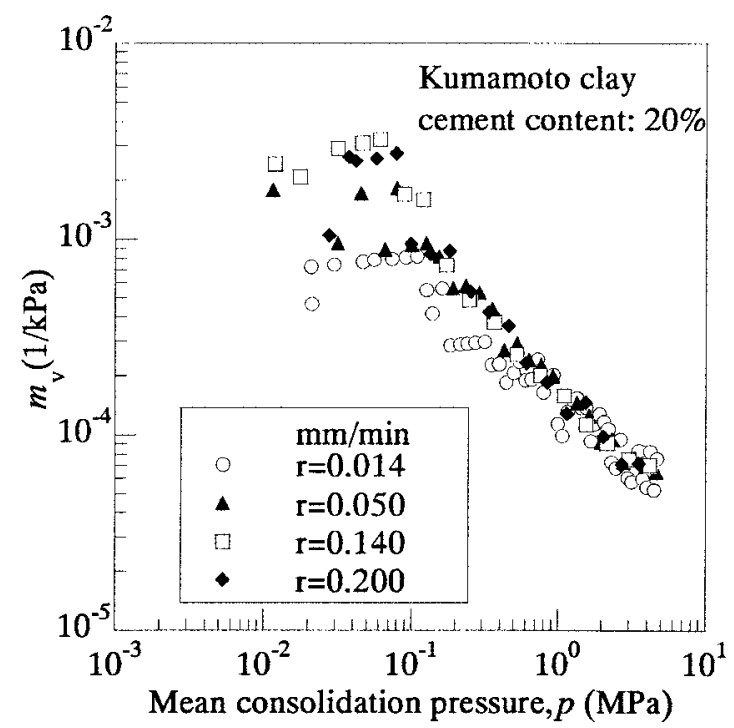

(b) Constant strain rate

Fig. 7. Coefficient of volume compressibility, $m_{\mathrm{v}}$

specimens. Therefore, it can be concluded that $e-\log p_{\mathrm{t}}$ of cement-treated clays is greatly affected by the constant strain rate and the cement content. It can be followed that the cement-treated clay becomes less compressive with increasing elapsed time from cement-mixing. By reconsidering these results for the purpose of increasing the density of cement-treated clay effectively, it can be concluded that it is useful to dehydrate the cement mixture with a large dehydration speed immediately following cement-mixing.

\section{Coefficient of Volume Compressibility}

Figures 7(a) and 7(b) show the coefficient of volume compressibility $m_{\mathrm{v}}$ for cement-treated Kumamoto clay with $r=0.140 \mathrm{~mm} / \mathrm{min}$ and cement content $=20 \%$, respectively. Although there is some scatter in the test results, especially at low mean consolidation pressure, similar $m_{\mathrm{v}}$ for a given mean consolidation pressure was observed irrespective of cement content and constant strain rate. Accordingly, it can be considered that $m_{\mathrm{v}}$ of cement-treated clay is equivalent to that of untreated clay irrespective of cement content and dehydration speed.

\section{Coefficient of Consolidation}

Figure 8 is the coefficient of consolidation $c_{\mathrm{v}}$ for cement-treated Kumamoto clay with $r=0.200 \mathrm{~mm} / \mathrm{min}$ showing that $c_{\mathrm{v}}$ greatly decreases up to about $10^{-1} \mathrm{MPa}$ and then keeps almost constant value similar to untreated clay. It can be emphasized that $c_{\mathrm{v}}$ for a given mean consolidation pressure increases in proportion to cement content. In order to evaluate the effect of cement content and constant strain rate on the coefficient of consolidation, $c_{\mathrm{v}}$ at mean consolidation pressure of $1 \mathrm{MPa}$ is plotted as a function of constant strain rate $r$ in Fig. 9. It 


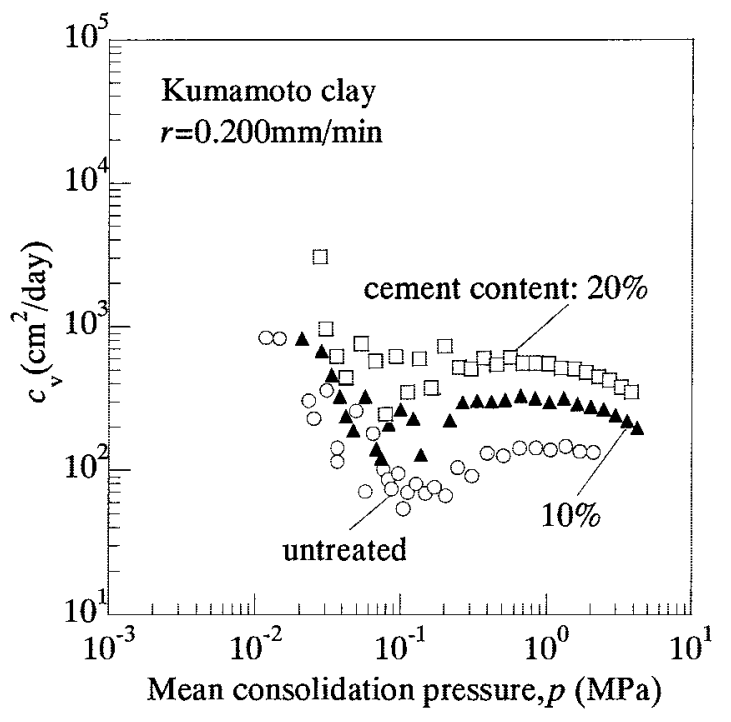

Fig. 8. $\quad c_{\mathrm{v}}$ and mean consolidation pressure

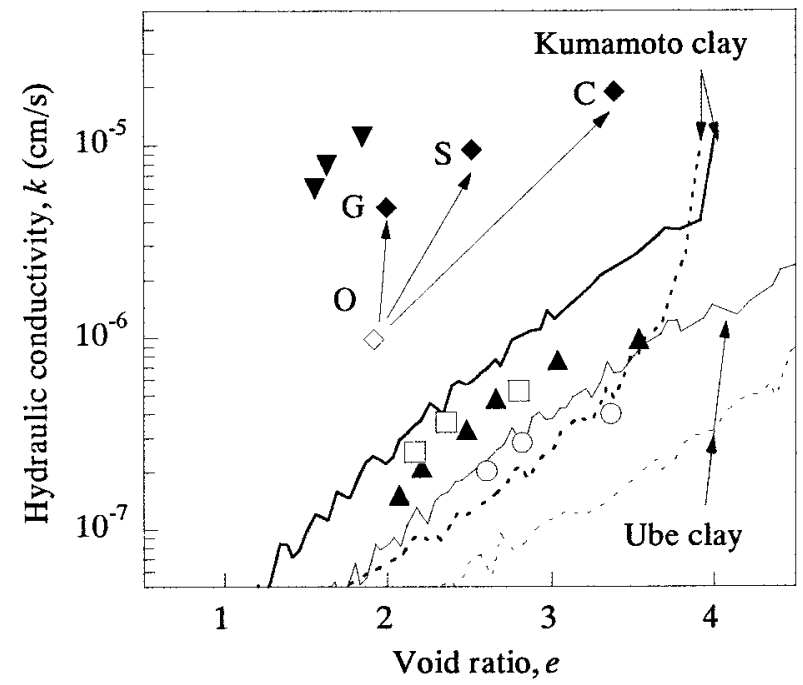

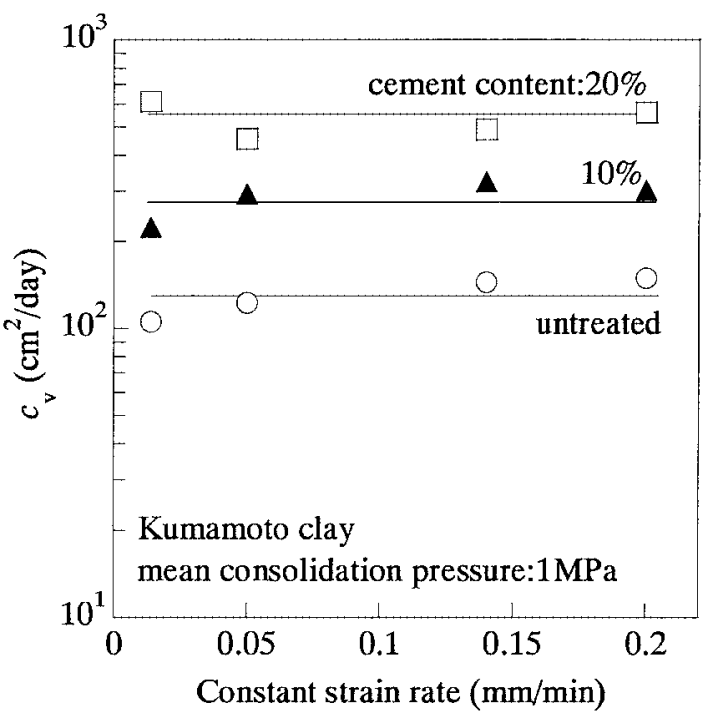

Fig. 9. $c_{\mathrm{v}}$ at $1 \mathrm{MPa}$ and constant strain rate

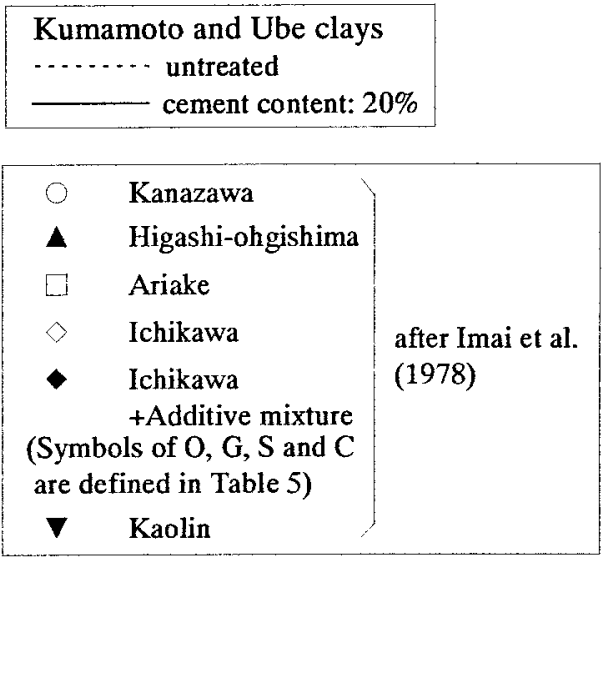

Fig. 10. Hydraulic conductivity and void ratio, after Imai et al. (1978)

can be seen that $c_{\mathrm{v}}$ at the mean consolidation pressure of $1 \mathrm{MPa}$ is almost constant parameter irrespective of $r$, and thus the magnitude of $c_{\mathrm{v}}$ for cement content $=10 \%$ and $20 \%$ are about 2.5 and 5.0 times that of untreated clay, respectively. Therefore, it is expected that the dehydration of cement-treated clay following cementmixing is temporarily accelerated as the cement content increases.

\section{Hydraulic Conductivity and Void Ratio}

In order to evaluate the effect of increasing cement content on the hydraulic conductivity of cement-treated clays, the hydraulic conductivity $k\left(=m_{\mathrm{v}} \times c_{\mathrm{v}} \times \gamma_{\mathrm{w}}\right)$ calculated by measured $m_{\mathrm{v}}$ and $c_{\mathrm{v}}$ is shown against void ratio in Fig. 10. The test results of five clays reported by Imai et al. (1978) are also shown in Fig. 10. The physical properties of these clays and the additive mixtures for Ichikawa clay are shown in Tables 4 and 5 respectively. It should be noted that the activity, $A$, in Table 4 was a plasticity index divided by the percentage of clay fraction smaller than 2 microns. Imai et al. (1978) found that the hydraulic conductivity of clay increased with decreasing activity $A$. It can be characterized that $k$ of cement-treated Kumamoto and Ube clays for a given void ratio increase with increasing cement content similar to Ichikawa clay with the additive mixture. Similarly, Katsumata et al. (1997) reported that cement agents were more effective materials for dehydration of clay with high water content clay than a general flocculant such as PAC (poly aluminum chloride) from the test results of filter test according to API standard (American Petroleum Institute standard). Moreover, Sogabe et al. (1996) reported that sedimentation velocity of clay particles increases with the addition of cement, which was considered to be caused by the flocculation of clay particles due to the chemical cohesion of cement agent. 
Table 4. Physical properties of tested material, after Imai et al. (1978)

\begin{tabular}{l|c|c|c|c|c}
\hline \multicolumn{1}{c|}{ Source } & $\begin{array}{c}\rho_{\mathrm{s}} \\
\left(\mathrm{Mg} / \mathrm{m}^{3}\right)\end{array}$ & $\begin{array}{c}\text { Liquid } \\
\text { limit } \\
(\%)\end{array}$ & $\begin{array}{c}\text { Plasticity } \\
\text { index }\end{array}$ & $\begin{array}{c}\text { C.F.* } \\
(\%)\end{array}$ & A $^{* *}$ \\
\hline Kumamoto clay & 2.614 & 101.0 & 63.8 & 42.0 & 1.52 \\
\hline Ube clay & 2.571 & 132.0 & 90.9 & - & - \\
\hline Kanazawa & 2.615 & 118.1 & 82.3 & 41.8 & 1.97 \\
\hline Higashi-ohgishima & 2.669 & 113.7 & 80.2 & 50.5 & 1.59 \\
\hline Ariake & 2.685 & 105.4 & 67.2 & 54.0 & 1.24 \\
\hline Ichikawa & 2.674 & 83.8 & 51.7 & 39.0 & 1.33 \\
\hline Kaorin & 2.713 & 45.8 & 16.4 & 31.5 & 0.52 \\
\hline
\end{tabular}

${ }^{*}$ C.F.: Clay fraction smaller than 2 microns

${ }^{* *}$ A: Activity (Plasticity index/C.F.)

Table 5. Additive mixtures for Ichikawa clay, after Imai et al. (1978)

\begin{tabular}{c|c|c}
\hline Symbol & Additive mixture & $\begin{array}{r}\text { Additive weight to } \\
\text { specimen weight }\end{array}$ \\
\hline $\mathrm{O}$ & None & $0 \mathrm{ppm}$ \\
\hline $\mathrm{G}$ & Waterglass & $200 \mathrm{ppm}$ \\
\hline $\mathrm{S}$ & $\begin{array}{c}\text { Waterglass } \\
+ \text { Slake lime }\end{array}$ & $\begin{array}{r}200 \mathrm{ppm} \\
+20,000 \mathrm{ppm}\end{array}$ \\
\hline $\mathrm{C}$ & $\begin{array}{c}\text { Waterglass } \\
+ \text { Portland cement }\end{array}$ & $\begin{array}{c}200 \mathrm{ppm} \\
+20,000 \mathrm{ppm}\end{array}$ \\
\hline
\end{tabular}

\section{UNCONFINED COMPRESSIVE STRENGTH}

\section{Sample Preparation and Test Procedure}

In order to evaluate the effect of mechanical dehydration with high pressure on the unconfined compressive strength of cement-treated clay, dehydrated cementtreated specimens were prepared as a function of cement content, dehydration pressure and dehydration mode. Figure 11 shows the schematic diagram of the mold to dehydrate cement-treated clay. The inner mold size is $(\phi) 50 \mathrm{~mm} \times$ (height) $250 \mathrm{~mm}$. The characteristics of the mold are following;

(1) In order to facilitate dehydration from specimen, paper drains were placed at the top and the bottom of specimen and also around of the cylindrical surface of specimen.

(2) The specimen was dehydrated under two dehydration modes. One was that loading plate on the top of specimen was pressed at constant strain rate of 1.0 $\mathrm{mm} / \mathrm{min}$ (called "constant strain mode"). The other was that specimen was dehydrated under constant stress (called "constant stress mode") until the consolidation was completed based on the judgment employing the $3 t$ method (JGS, 1999).

(3) As for constant strain mode, the specimen with initial height of $200 \mathrm{~mm}$ was dehydrated until the height was $100 \mathrm{~mm}$, which is the standard size of specimen $(50 \mathrm{~mm}$ in diameter and $100 \mathrm{~mm}$ in height) for unconfined compression test. Thus, the specimens after the dehydration could be directly used for unconfined
Table 6. Sample preparation for dehydrated cement-treated clay

\begin{tabular}{l|l|l}
\hline Soil & \multicolumn{2}{|l}{ Kumamoto clay } \\
\hline Cement type & Portland blast-furnace slag cement type B \\
\hline Dehydration mode & $\begin{array}{l}\text { Constant strain mode } \\
(1 \mathrm{~mm} / \mathrm{min})\end{array}$ & $\begin{array}{l}\text { Constant stress mode } \\
5,10,15,20 \mathrm{MPa}\end{array}$ \\
\hline Cement content & $10,15,20 \%$ & $10,15,20,30 \%$ \\
\hline Initial water content & $1.5 w_{\mathrm{L}}$ & \\
\hline Curing period & $7,28,91$ days \\
\hline Curing condition & Temperature $=21 \pm 3^{\circ}$, Humidity $\geq 95 \%$ \\
\hline
\end{tabular}

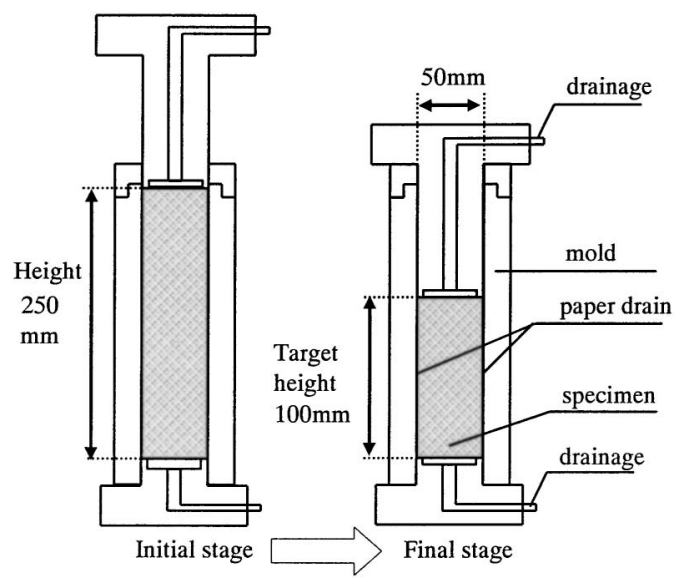

Fig. 11. Schematic diagram of mold for mechanical dehydration

compression test.

(4) As for dehydration pressure in constant stress mode, 5, 10, 15, $20 \mathrm{MPa}$ were selected. The initial height of specimen was $250 \mathrm{~mm}$. After dehydration, the height of specimens was adjusted by cutting to fit the standard size of specimen for unconfined compression test.

The sample preparation for dehydrated cement-treated clay is summarized in Table 6 . In order to examine the variability of density in the dehydrated specimen, the water content in vertical direction of dehydrated specimen was measured. Moreover, a series of unconfined compression tests were carried out for dehydrated specimens cured for 27 days under the standard curing condition (the temperature of $21 \pm 3^{\circ}$ and the humidity of more than $95 \%$ ).

\section{Constant Strain Mode and Constant Stress Mode}

Figure 12 shows the relationships between dehydration pressure and elapsed time from starting of dehydration for dehydrated specimens with constant strain mode showing that the dehydration pressure gradually increases at the low range of dehydration pressure and then increases sharply with increasing elapsed time. The dehydration pressure for a given elapsed time increases with increasing cement content, which follows that the dehydration pressure for the specimen with cement content of $20 \%$ is about 1.5 times that of $10 \%$ cement content specimen at the end of dehydration. 


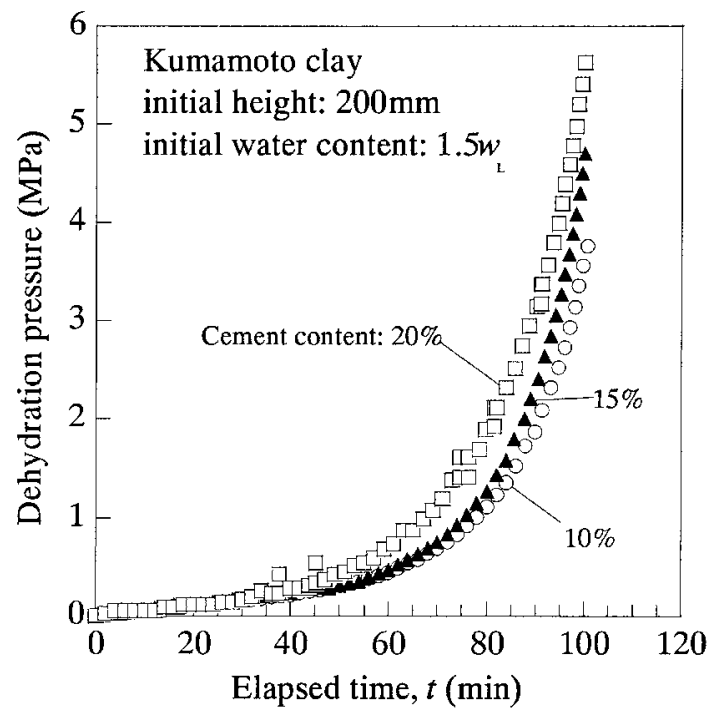

Fig. 12. Dehydration pressure and elapsed time under constant strain mode

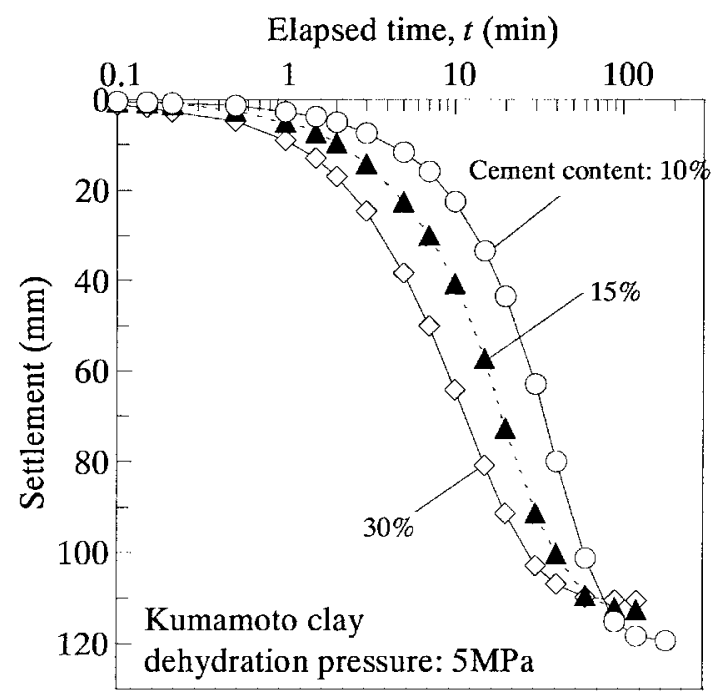

Fig. 13. Time-settlement curve under constant stress mode

Figure 13 is the time-settlement curve for the dehydrated specimen with constant stress mode, which is similar to a typical time-settlement curve of cohesive soils. It can be seen that settlement for a given elapsed time increases with increasing cement content while the final settlement at the end of dehydration decreases with increasing cement content, which suggests that the dehydration of cement-treated clays is accelerated as cement content increases as expected from the result of constant strain rate consolidation test for cement-treated clay in prior section.

\section{Distributions of Water Content}

In order to examine the variability of density in the dehydrated specimen, the water content in the vertical direction of the specimen is shown in Fig. 14. The vertical axis in Fig. 14 is normalized by the height of the specimen. It can be seen that there is a local difference of water

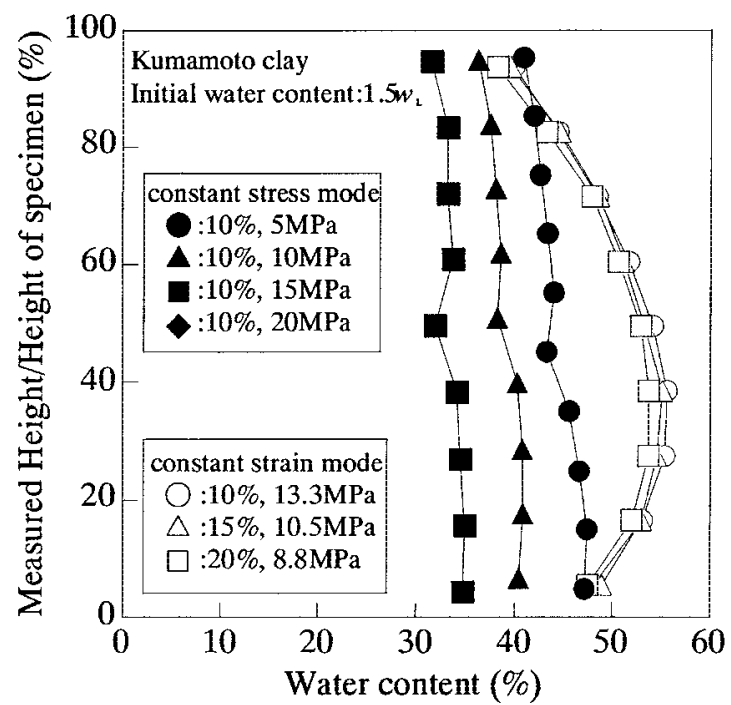

a) Vertical direction

Fig. 14. Water content of specimen in vertical directions

content in the specimen and thus the water content for dehydrated specimen with constant stress mode is smaller than that for dehydrated specimen with constant strain mode for a given dehydration pressure. In addition, the difference of maximum and minimum water contents for dehydrated specimens with constant strain mode is larger than that for dehydrated specimens with constant stress mode. As the variability of water content in specimens has influence on the strength of specimen, it is expected that specimen dehydrated with constant strain mode shows lower strength than that for dehydrated specimen with constant stress mode. Subsequently, it can be suggested that the constant stress mode is better than constant strain mode for the purpose of increasing the specimen density uniformly and effectively.

\section{Unconfined Compressive Strength}

Figure 15 shows the unconfined compressive strength $q_{\mathrm{u}}$ of dehydrated cement-treated clays as a function of dehydration pressure and cement content for specimens cured for 28 days. It can be seen that $q_{\mathrm{u}}$ sharply increases up to the dehydration pressure of $5 \mathrm{MPa}$ and then increases constantly while the increase rates of strength against dehydration pressure depend on the cement content and dehydration mode. Although $q_{\mathrm{u}}$ increases with cement content in both of dehydration modes, $q_{\mathrm{u}}$ for constant stress mode is larger than that for constant strain mode. It is worth noting that cement-treated clay dehydrated with constant stress mode achieve a target strength of $20 \mathrm{MPa}$ (maximum $q_{\mathrm{u}}=25 \mathrm{MPa}$ ) while the $q_{\mathrm{u}}$ of cement-treated clay without mechanical dehydration is about $1.1 \mathrm{MPa}$ for cement content of $30 \%$.

In order to evaluate the specimen density on unconfined compressive strength of cement-treated clay, $q_{\mathrm{u}}$ is plotted against the dry density of specimen in Fig. 16. The dry density used here is the mean value in the dehydrated specimen although there is a variability of density in dehydrated specimen as shown in prior section. It is seen 


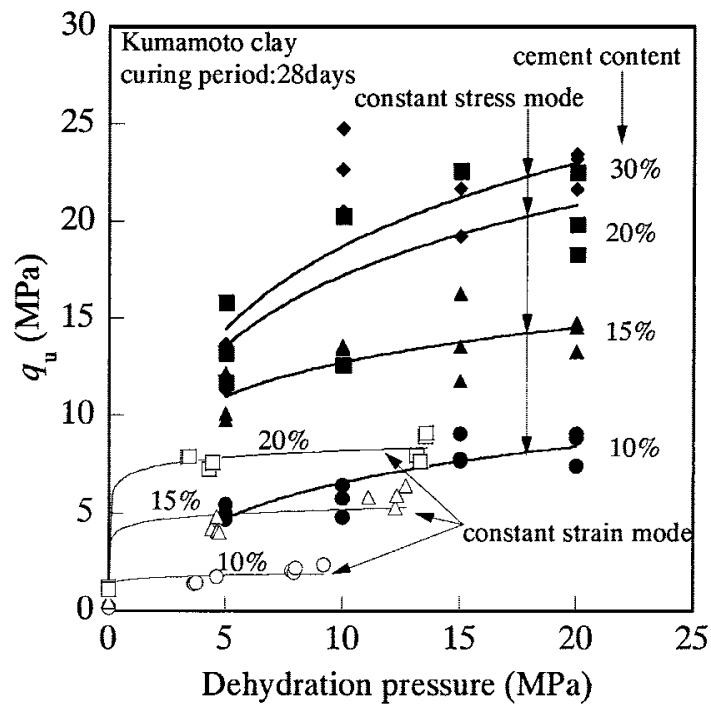

Fig. 15. $q_{\mathrm{u}}$ against dehydration pressure

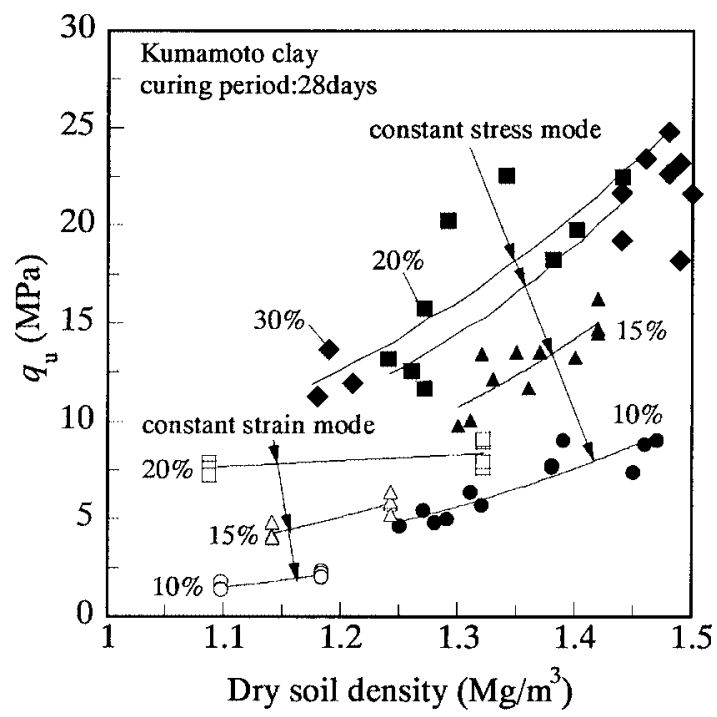

Fig. 16. $q_{\mathrm{u}}$ and dry soil density

that $q_{\mathrm{u}}$ increases with the increasing dry density and also increasing cement content while the increase rate of strength is different for both dehydration modes. The difference of $q_{\mathrm{u}}$ between constant strain and constant stress modes for a given dry density are related to the local difference of density in dehydrated specimens, which is linked to the difference of failure pattern for specimen after unconfined compression test. Namely, the specimens dehydrated with constant strain mode generally broke into pieces around the middle part of specimens showing a high water content (as shown in Fig. 14) while specimens dehydrated with constant stress mode show a typical failure pattern with an inclined shear crack through the specimen similar to concrete. Moreover, as there is no strength increase for specimens mixed with cement of over $20 \%$ under constant stress dehydration, it is suggested that there is an upper limit for the unconfined compressive strength obtained by the CMD although the correlations of cement content with specimen density

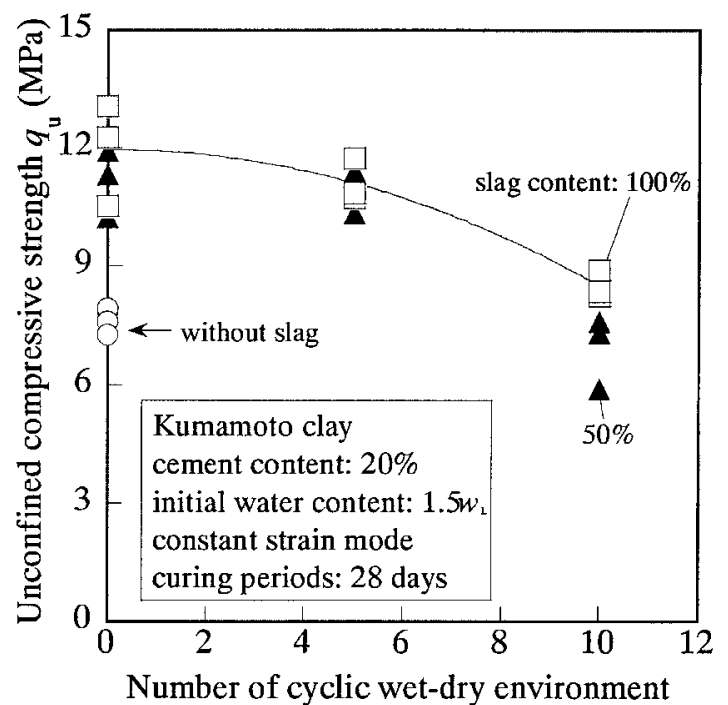

Fig. 17. $q_{\mathrm{u}}$ under cyclic wet-dry environment

produced with the CMD should be clarified in future studies.

\section{DURABILITY AND CURING CONDITION}

Sample Preparation and Test Procedure

Sekine et al. (1996) and Rollings et al. (1999) have reported the durability of cement-treated clay suggesting that the strength of specimen drastically decreases under cyclic wet-dry environment due to cracks generated inside the specimen. In this study, in order to improve the durability of specimen produced by the CMD, a blastfurnace slag was mixed together with cement before the mechanical dehydration for the purpose of reinforcing the soil structure of specimen taking advantage of the latent hydraulicity of a blast-furnace slag. In order to examine the improvement effect of mixing a blast-furnace slag on the durability of specimen produced by the CMD, a series of durability tests were performed for dehydrated cement-treated clay with a blast-furnace slag $\left(\rho_{\mathrm{s}}=2.640\right.$ $\mathrm{Mg} / \mathrm{m}^{3}, U_{\mathrm{c}}=2.2, D_{50}=0.59, F_{\mathrm{c}}=1.57 \%$ ) cured for 28 days. The content of a blast-furnace slag in specimen was $50 \%$ and $100 \%$ per dry soil sample weight (called "slag content"). As for durability tests, unconfined compression tests after cyclic wet-dry environment, slaking tests according to JHS-110 (Japan Highway Standard, 1992), water absorption tests according to JHS-111 (JHS, 1992), abrasion resistance tests according to ASTM C-779 and swelling tests due to water absorption were performed for dehydrated cement-treated specimens with cement content of $20 \%$ and constant strain mode.

\section{Durability and Improvement Effect of Slag}

Figure 17 shows $q_{\mathrm{u}}$ of dehydrated cement-treated specimens as a function of the cyclic wet-dry environment. It should be noted that one cycle of wet-dry environment means that specimen was exposed in underwater condition with the temperature of $25^{\circ}$ for a day and then in dry condition with the temperature of $110^{\circ}$ for a day. It was 


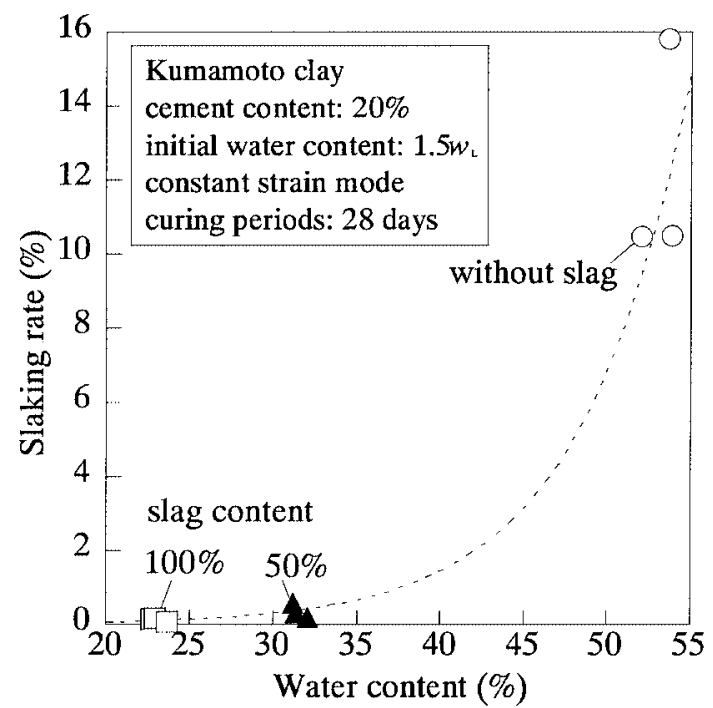

Fig. 18. Slaking rate against water content

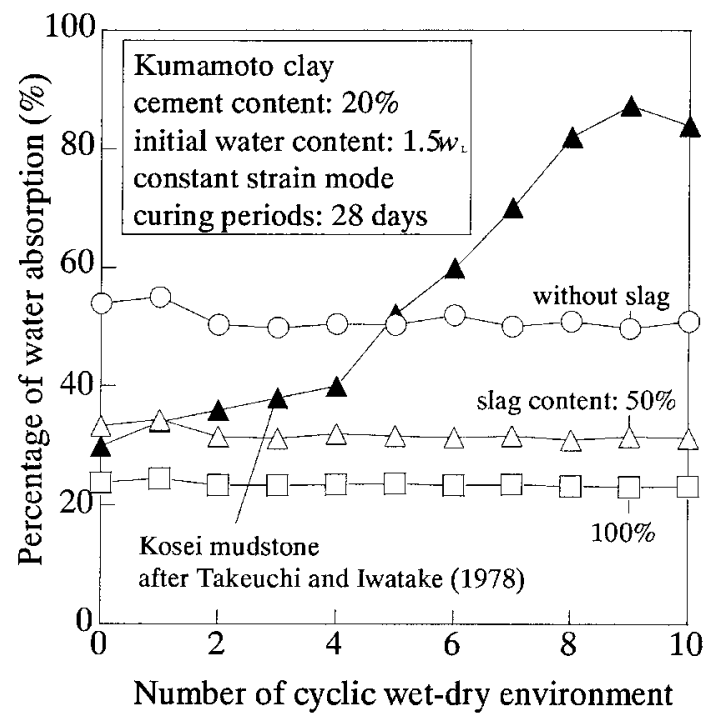

Fig. 19. Water absorption under cyclic wet-dry environment

observed that the specimens without slag broke into pieces after only one time of the cycle wet-dry environment, which follows that dehydrated cement-treated clay is vulnerable to a sharp thermal change similar to cementtreated clay. On the other hand, the ruin of specimens can be prevented by mixing slag irrespective of the number of cyclic wet-dry environment and thus the $q_{\mathrm{u}}$ for specimen with slag does not show drastic reduction in addition that the $q_{\mathrm{u}}$ prior to cyclic wet-dry environment increases with increasing slag content.

Figure 18 is the test result of slaking tests showing that the slaking rate for dehydrated cement-treated specimens with slag $50 \%$ and $100 \%$ were less than $1 \%$ while those of specimen without slag was $10-15 \%$. One of reasons for decreasing slaking rate by mixing slag is that the shrink of specimen due to water evaporation can be prevented by increasing slag content and also it is effective for reinforcing the soil structure of specimen by mixing slag.

Figure 19 shows the percentage of water absorption

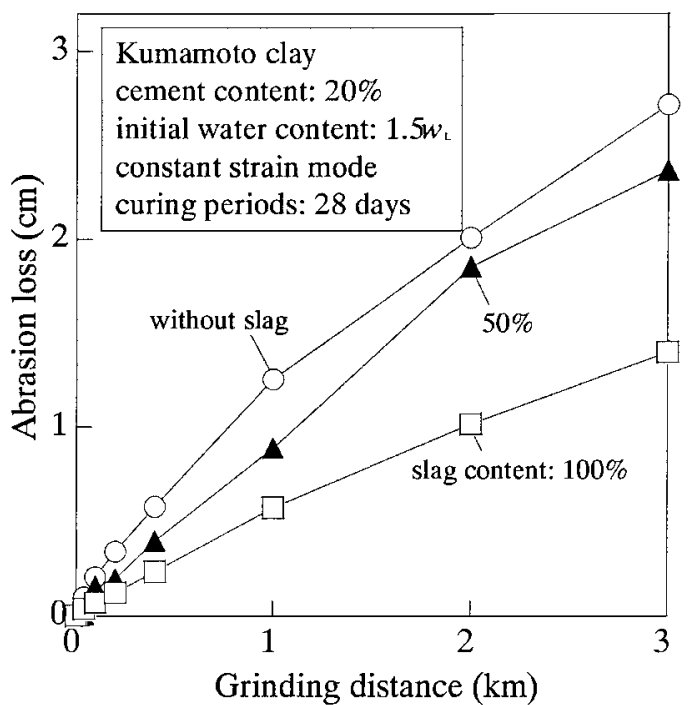

Fig. 20. Abrasion loss against grinding distance

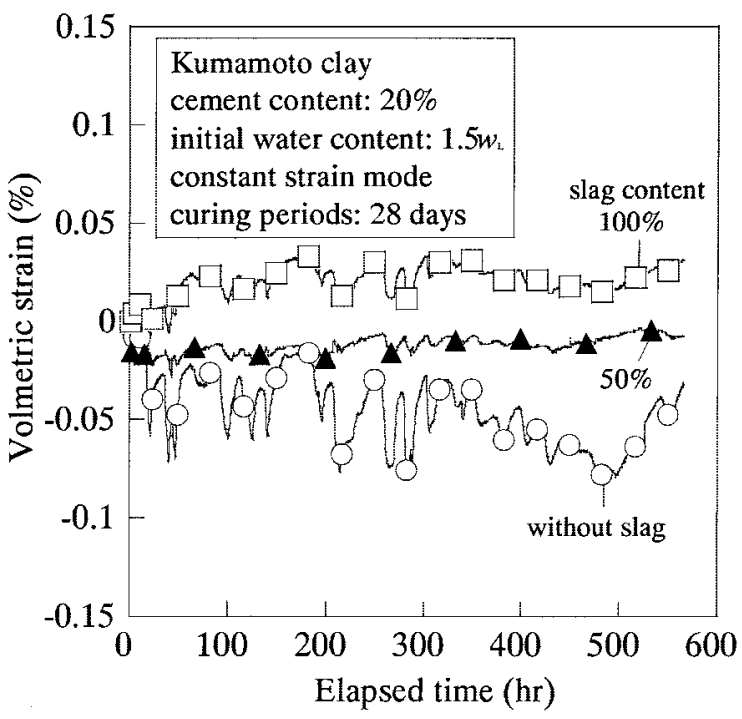

Fig. 21. Volumetric strain against elapsed time

against the number of cyclic wet-dry environment. The test result of Kosei mudstone, which was one of typical mudstones with a vulnerability to cyclic wet-dry environment reported by Takeuchi and Iwatake (1978), is also shown in Fig. 19. It can be seen that the percentage of water absorption for dehydrated cement-treated specimens indicate almost constant value decreasing with slag content while that for the Kosei mudstone increases with number of cyclic wet-dry environment.

Figure 20 shows the test result of abrasion resistance tests for dehydrated cement-treated specimen. The abrasion resistance tests according to ASTM C-779 have been used to evaluate the abrasion resistance of concrete material, in which specimens loaded by $8.8 \mathrm{kPa}$ were ground against Toyoura sand measuring the grinding loss of specimen (call "abrasion loss") and grinding distance. Large abrasion loss refers to vulnerable materials to abrasion. It can be seen that the abrasion loss of dehydrated cement-treated specimen linearly increases 
Table 7. The influence of curing condition for the unconfined compressive strength

\begin{tabular}{|c|c|c|c|c|}
\hline Cement content & Slag content & $\begin{array}{l}\text { Curing } \\
\text { condition }\end{array}$ & $\begin{array}{l}\text { Dehydration } \\
\text { mode }\end{array}$ & $q_{\mathrm{u}}$ at 91 days \\
\hline \multirow{7}{*}{$20 \%$} & \multirow{3}{*}{$0 \%$} & Standard* & \multirow{7}{*}{$\begin{array}{l}\text { Constant } \\
\text { strain mode }\end{array}$} & $10.4 \mathrm{MPa}$ \\
\hline & & Air** & & $3.9 \mathrm{MPa}$ \\
\hline & & Underwater $* * *$ & & $8.2 \mathrm{MPa}$ \\
\hline & $50 \%$ & Standard* & & $16.4 \mathrm{MPa}$ \\
\hline & \multirow{3}{*}{$100 \%$} & Standard* & & $21.3 \mathrm{MPa}$ \\
\hline & & Air** & & $9.1 \mathrm{MPa}$ \\
\hline & & Underwater & & $23.3 \mathrm{MPa}$ \\
\hline \multirow{3}{*}{$30 \%$} & \multirow{3}{*}{$0 \%$} & Standard* & \multirow{3}{*}{$\begin{array}{l}\text { Constant } \\
\text { stress mode } \\
20 \mathrm{MPa}\end{array}$} & $29.9 \mathrm{MPa}$ \\
\hline & & Air** & & $28.9 \mathrm{MPa}$ \\
\hline & & Underwater*** & & $23.9 \mathrm{MPa}$ \\
\hline
\end{tabular}

$*$ : Temperature $21 \pm 3^{\circ}$, Humidity $\geq 95 \%$

**: Temperature $21 \pm 3^{\circ}$, Humidity $\leq 10 \%$

$* * *$ : Temperature $21 \pm 3^{\circ}$

with grinding distance, but decreases with increasing slag content.

Figure 21 shows the volumetric strain due to water absorption as a function of the elapsed time after submerging specimens into underwater. It can be seen that the volumetric strain for specimens with slag was so small and stable irrespective of the slag content that the swelling of specimen due to water absorption can be ignored in practical use. From the test results of several durability tests, it can be concluded that it is effective to mix cement-treated clay with slag before mechanical dehydration for improving the durability of dehydrated cement-treated clay.

In order to examine the influence of curing condition on the strength of dehydrated cement-treated specimen, unconfined compression tests were performed for the specimen cured for 91 days under air condition (the temperature of $21 \pm 3^{\circ}$ and the humidity less than $10 \%$ ), standard curing condition (the temperature of $21 \pm 3^{\circ}$ and the humidity of more than $95 \%$ ) and underwater condition (the temperature of $21 \pm 3^{\circ}$ ) respectively. Table 7 summarizes $q_{\mathrm{u}}$, dehydration mode, slag content, cement content and curing condition. It can be seen that $q_{\mathrm{u}}$ of specimens with constant strain mode for underwater condition was almost equal to that of standard curing condition while $q_{\mathrm{u}}$ of air condition was less than half of underwater condition due to cracks in specimen induced by the dry shrinkage of specimen. On the other hand, $q_{\mathrm{u}}$ in constant stress mode was more than $20 \mathrm{MPa}$ for three curing conditions. Although further investigation on the long-term influence of curing condition on the strength of dehydrated cement-treated specimen will be needed, it can be concluded that dehydrated cement-treated clay maintain the high-strength in both of standard curing and underwater conditions.

\section{CONCLUSIONS}

This study has investigated the unconfined compressive strength property and durability of soft clay treated by cement-mixing and mechanical dehydration with high pressure together with the literature review of sample preparation for increasing the unconfined compressive strength of cement-treated soils. Moreover, a series of constant strain rate consolidation tests were performed to evaluate the effect cement-mixing on the dehydration property of soft clay.

The following conclusions are obtained:

(1) The literature review and theoretical considerations on the shear strength of cement-treated soil show that additional treatments for the purpose of increasing the density of cement-treated specimen, such as consolidation and compaction, are effective for increasing the unconfined compressive strength of cement-treated soil.

(2) The dehydration properties of cement-treated clay depend on the elapsed time after cement-mixing in addition to cement content, which is attributed to the chemical reactions of cement agent. It can be concluded that the dehydration of soft clay with mechanical dehydration is accelerated by cement mixing, where the coefficient of consolidation $c_{\mathrm{v}}$ of cement-treated clay for the cement content of $10 \%$ and $20 \%$ are about 2.5 and 5.0 times that of untreated clay.

(3) The mean unconfined compressive strength for Kumamoto clay mixed with cement content of over $20 \%$ and dehydrated with constant stress of $20 \mathrm{MPa}$ is almost $20 \mathrm{MPa}$, which is comparable to concrete material. It can be concluded that mechanical dehydration following cement-mixing for the purpose of increasing the density of cement-treated specimen is effective for increasing the unconfined compressive strength.

(4) While cement-treated clay dehydrated with high pressure is vulnerable to a sharp thermal change similar to cement-treated clay, it is useful to mix cement-treated 
clay with blast-furnace slag for improving the durability. Although the unconfined compressive strength of dehydrated cement-treated clay reduce with elapsed time in cyclic wet-dry environment and dry condition (the temperature of $21 \pm 3^{\circ}$ and the humidity less than $10 \%$ ), the unconfined compressive strength is stable under underwater condition and wet condition such as the temperature of $21 \pm 3^{\circ}$ with the humidity of more than $95 \%$.

\section{ACKNOWLEDGEMENT}

The result of literature search by the technical committee of JGS on the engineering property and test method of cement-treated soil was partly used in the literature review of the unconfined compressive strength of cementtreated soils in this study. A grateful acknowledgement is made to Professor Hidetoshi Ochiai, Associate Professor Guangqi Chen, Associate Professor Noriyuki Yasufuku and Associate Professor Kiyoshi Omine of Kyushu University for their helpful advice and encouragement.

\section{NOTATION}

$s_{\mathrm{u}}$ : undrained shear strength

$\alpha$ : inclination of failure envelop in normally consolidated state in $p^{\prime}-q$ space

$p_{\mathrm{r}}^{\prime}$ : cementation parameter

$p_{\mathrm{c}}^{\prime}$ : consolidation pressure

$p_{\mathrm{y}}^{\prime}$ : consolidation yield stress

$R:$ yield stress ratio

$p_{\mathrm{t}}$ : consolidation pressure during one-dimensional test using constant rate of strain loading

\section{REFERENCES}

1) Clough, G. W., Sitar, N., Bachus, R. C. and Rad, N. S. (1981): Cemented sands under static loading, J. Geotech. Engrg., ASCE, 107(6), 799-817.

2) Consoli, N. C., Rotta, G. V. and Prietto, P. D. M. (2000): Influence of curing under stress on the triaxial response of cemented soils, Geotechnique, 50(1), 99-105.

3) Elkins, B. V. and Thompson, T. K. (1997): Recycle dredge materials for beneficial use, Dredging and Management of Dredged Material, Geotechnical Special Publication 65, ASCE, 161-176.

4) Imai, G., Mori, K. and Yamada, S. (1978): Forced dewatering characteristics and disposal efficiency of fluid mud, Soils and Foundations, 18(3), 13-25.

5) Kamon, M., Gu, H. and Katsumi, T. (1999): Engineering properties of soil stabilized by ferrum lime and used for the application of road base, Soils and Foundations, 39(1), 31-41.

6) Kasama, K., Zen, K., Chen, G. and Egashira, K. (2002): High strengthening of dredged clay by cement mixing and mechanical dehydration, Proc. Symposium on Recent Development of Research and Practice in Clayey Ground, 235-240.

7) Kasama, K., Zen, K. and Iwataki, K. (2006): Undrained shear strength of cement-treated soils, Soils and Foundations, 46(2), 221-232.

8) Katsumata, M., Takiguchi, K., Shimizu, H. and Obayashi, S. (1997): The development of a system to dehydrate construction slurry, J. Construction Management and Engineering, JSCE, 560(VI-34), 117-129 (in Japanese).

9) Kusakabe, S. and Morio, S. (1995): A proposal of duplication method for naturally cemented sensitive clays and its compression and shear deformation behavior,' J. Geotech. Engrg., JSCE, 511(III-30), 145-154 (in Japanese).

10) Larsson, S. (2001): Binder distribution in lime-cement columns,
Ground Improvement, 5(3), 111-122.

11) Mayne, P. W. (1980): Cam-clay prediction of undrained strength, J. Geotech. Engrg., ASCE, 106(11), 1219-1242.

12) Mishima, N., Morimoto, Y., Imayoshi, H. and Kobayashi, H. (1995): Long term strength properties of stabilized soils, Proc. 30th Jpn. Nat. Conf. JSSMFE, 2203-2204 (in Japanese).

13) Mitachi, T. and Kitago, S. (1976): Change in undrained shear strength characteristics of saturated remould clay due to swelling, Soils and Foundations, 16(1), 45-58.

14) Miura, N., Horpibulsuk, S. and Nagaraj, T. S. (2001): Engineering behavior of cement stabilized clay at high water content, Soils and Foundations, 41(5), 33-45.

15) Morita, Y., Yamada, K., Aihara, A., Saito, S. and Sai, K. (1992): Use for excavated soil improved by adding cement and applying pressure, Proc. 27th Jpn. Nat. Conf. JSSMFE, 2361-2362 (in Japanese).

16) Murthy, M. K., Sridharan, A. and Nagaraj, T. S. (1982): Prediction of undrained strength of over consolidated clays, Soils and Foundations, 22(1), 78-81.

17) Nakama, T., Ishibashi, M. and Saito, S. (1998): Fundamental study on laboratory mixing test for sandy ground improvement by deep cement mixing method (part II), Proc. 33rd Jpn. Nat. Conf. JSSMFE, 2201-2202 (in Japanese).

18) Netzband, A., Reincke, H. and Bergemann, M. (2002): The river Elbe a case study for the ecological and economical chain of sediments, J. Soils and Sediments, 2(3), 112-116.

19) Omine, K., Ochiai, H. and Yoshida, N. (1998): Estimation of in-situ strength of cement-treated soils based on a two-phase mixture model, Soils and Foundations, 38(4), 17-29.

20) Porbaha, A., Tsuchida, T. and Kishida, T. (1999): Technology of air-transported stabilized dredged fill. Part 2: quality assessment, Ground Improvement, 3, 59-66.

21) Rollings, R. S., Burkes, J. P. and Rollings, M. P. (1999): Sulfate attack on cement-stabilized sand, J. Geotech. Environ. Engrg., ASCE, 125(5), 364-372.

22) Rotta, G. V., Consoli, N. C., Prietto, P. D. M., Coop, M. R. and Graham, J. (2003): Isotropic yielding in an artificially cemented soil cured under stress, Geotechnique, 53(5), 493-501.

23) Sekine, E., Kito, M., Tarumi, H. and Yonezawa, T. (1996): A study on durability of chemically stabilized roadbed under repeated train load, J. Construction Management and Engineering, JSCE, 546(VI-32), 181-188 (in Japanese).

24) Sogabe, H., Aihara, A., Yamada, K., Saito, S. and Yamasaki, Y. (1996): Study on high pressure dewatering method of cementstabilized soft clay, J. Construction Management and Engineering, JSCE, 540(VI-31), 113-122 (in Japanese).

25) Takeuchi, T. and Iwatake, K. (1978): Weathering properties of a mudstone, Report of The Laboratory of Nihon Doro Kodan, 37-47 (in Japanese).

26) Tang, Y. X., Miyazaki, Y. and Tsuchida, T. (2001): Practices of reused dredging by cement treatment, Soils and Foundations, 41(5), 129-143.

27) Tay, J.-H., Show, K.-Y. and Hong, S.-Y. (2002): Concrete aggregates mode from sludge-marine clay mixes, J. Materials in Civil Engineering, ASCE, 14(5), 392-398.

28) Terashi, M. and Tanaka, H. (1981): Ground improved by deep mixing method, Proc. 10th ICSMFE, Stockholm, 3, 777-780.

29) The Japanese Geotechnical Society (1999): Standards of Japanese Geotechnical Society for Laboratory Shear Test (English version), 15.

30) Tsuchida, T., Porbaha, A. and Yamane, N. (2001): Development of a geomaterial from dredged bay mud, J. Materials in Civil Engineering, ASCE, 13(2), 152-160.

31) Watabe, Y., Tsuchida, T., Hikiyashiki, H. and Furuno, T. (2001): Mechanical and material properties of dredged soil treated with poor quantity of cement, Report of the Port and Airport Research Institute, 40(2), 1-22 (in Japanese).

32) Zou, D. H. and Li, L. P. (1999): Strengthening of solidified dilute tailings slurry, J. Geotech. Geoenviron. Engrg., ASCE, 125(1), $11-15$. 